\title{
Reading Psalm 13 as a Strategy for the Cathartic Release of Negative Emotion
}

\author{
SAMPSOn S. Ndoga (University OF Pretoria)
}

\begin{abstract}
Psalm 13 moves from debilitating circumstances registered therein into resolution in six short verses. This article explores the strategies that the psalmist employs in achieving such a release to engage with the reality of victims of war rape in their managing feelings of abandonment. The article utilises African hermeneutics primarily interested in meaning derived from the text and beyond the critical issues to interact with existential challenges. Due to the psychological nature of the victims of war rape atrocities and the post-traumatic disorders, cathartic release is envisioned in recognition that, for some, healing may remain unattainable. After closely analysing the psalm, the article ends with some considerations for deriving meaning as sought by the methodological premise.
\end{abstract}

KEYWORDS: Psalm 13, lament psalms, cathartic release, negative emotion, gendercide, African hermeneutics

\section{A INTRODUCTION}

The 2018 Nobel Peace Prize to the Congolese gynaecologist Denis Mukwege for his exceptional reconstructive surgery in repairing damage inflicted on women horrifically raped in conflict situations is a stark reminder of the urgent need for intervention in civil wars in Africa and elsewhere. Wartime rape, in what has come to be categorised as gendercide, ${ }^{1}$ is a global phenomenon that has attracted disenfranchised attention, making Mukwege's numerous recognitions, including the 2008 UN Human Rights Prize and 2009 African of the year, almost

\footnotetext{
Submitted: 17/02/2021; peer-reviewed: 08/05/2021; accepted: 11/05/2021. Sampson S. Ndoga, "Reading Ps 13 as a Strategy for the Cathartic Release of Negative Emotion," Old Testament Essays 34 no. 1 (2021): 254 - 267. DOI: https://doi.org/10.17159/2312-3621/2021/v34n1a14.

1 See Elizabeth Gerhardt, The Cross and Gendercide: A Theological Response to Global Violence against Women and Girls (Downers Grove: InterVarsity Press, 2014), in which she categorises all forms of assault to include domestic violence, physical and sexual, human trafficking, infanticide, genital mutilation and rape. Note that C. Ross, "The Longest War": Gendercide," Baptistic Theologies 9/1 (2017): 49-65, aptly refers to gendercide as the longest war.
} 
encumbering. ${ }^{2}$ African accounts of war rape, particularly in the Democratic Republic of Congo, are a current concern of Mukwege's Panzi Hospital which caters for over 3500 women a year requiring acute reconstructive surgery for horrific damage inflicted during rape. ${ }^{3}$ The rarely reported and most severe form of violence against women that utterly paralyses any form of resistance to aggression by the victim, given the obvious upper hand the perpetrator(s) wields, has longstanding post-traumatic effects. Helplessness and haplessness in the moment of attack, stigmatisation and self-blame/hate thereafter, suggest the debilitating inability to return to any semblance of normality. It is with this in mind that the concept cathartic release is employed in this article with reference to the reading of Ps 13 .

Cathartic release is a psychoanalytic concept that takes a cue from its Greek origin for cleansing or purging to denote the relieving of emotions associated with traumatic experiences. ${ }^{4}$ The envisaged therapy recognises the inability of the approach to reverse completely latent memories of the trauma as well as the individual uniqueness of processing and coping mechanisms. This article analyses a lament psalm with a view to investigate the strategies the psalmist adopts to overcome his unfathomable depths of despair. The circumstances of the psalmist are not mentioned and admittedly dissimilar to those of the victims we have in mind here. The common denominator, if any, resides in the sense of abandonment, silence and absence of God in the midst of unbearable suffering. Lament psalms, as Waltman suggests, present the real-life expressions of the faithful in the context of the problematic silence of God without allowing his absence to exacerbate the abyss. ${ }^{5}$ While no answer is usually provided to such laments, as most scholars concur, ${ }^{6}$ this genre provides an experiential and emotive expression which in itself offers relief if not some

2 Wartime rape is well documented in East European conflicts as seen in a few studies populated here on the total helplessness and utter humiliation that paralyse victims. See Andrea Carolina Schvartz Peres, "Campos de Estupro: As Mulheres e a Guerra na Bósnia Rape Camps," Women and War in Bosnia $37 / 37$ (2010): 117-162.

3 See Nobel Peace Prize Winner: Denis Mukwege from DR Congo. Cited 18 November 2020. Online: https://www.bbc.com/news/world-africa-45759304.

4 See Thomas Scheff, "Catharsis and Other Heresies: A Theory of Emotion," Journal of Social, Evolutionary and Cultural Psychology 1/3 (2007): 98-113; James Honeycutt et al., "Individual Differences in Catharsis, Emotional Valence, Trauma Anxiety, and Social Networks among Hurricane Katrina and Rita Victims," Southern Communication Journal 73/3 (2008): 229-242.

5 Joshua C. Waltman, "Psalms of Lament and God's Silence: Features of Petition not Yet Answered," The Evangelical Quarterly 89/3 (2018): 209-221 (209).

6 See T. Boyer, "Psalms of Lament: Songs of a Fading Shadow," Pastoral Music 37/4 (2013): 22-24; Cf. M. Girard, "The Psalms of Lament," The Bible Today 48/3 (2010): 135-141; Gabriel Mendy, "The Theological Significance of the Psalm of Lament," American Theological Inquiry 8/1 (2010): 61-71; L.C. Jones, "The Psalms of Lament and the Transformation of Sorrow," The Journal of Pastoral Care and Counseling 61/12 (2007): 47-58. 
semblance of therapy. Joo reminds us of the inevitability of suffering, as his call for a theological and liturgical re-appropriation of lament psalms towards redressing suffering resonates with the intentions of this article. ${ }^{7}$ The question of particular interest here is whether there are insights that can be drawn from Ps 13 towards relieving contemporary suffering given the common desire for deriving meaning in such circumstances. After all, deriving meaning from a text is the chief aim of African hermeneutics utilised in this article.

African hermeneutics is complementary to Western approaches that are mostly text focused. With the decolonisation call that has since gathered momentum, African scholars have successfully introduced their own unique approach to biblical texts in which the scholarly obsession with the textual phenomena is not the terminus. Seminal work by what seemed like lone African scholarly voices were few and far between and include Kato, Mbiti, Bediako and Tienou, but have become prominently regular through the continued works of Adamo, Bin-Kapela, Dube et al, Masenya and Ngwa and others who have poked holes in the bubble of western hermeneutics' dominance. ${ }^{8}$ As West and De Wit ${ }^{9}$ attempt to show in a conciliatory quest for shared meaning between African and European readers, the pursuit is not a replacement necessarily, but it allows a hermeneutic that apportions engagement with contextual realities given the absence of such African concerns in European hermeneutics. ${ }^{10}$ An approach that

7 Jonghun Joo, "The Psalms of Lament: Prospect for Renewing Kenyan Evangelical Worship,” Worship 91 (2017): 351-367 (351).

8 Byang Kato, Biblical Christianity in Africa: A Collection of Papers and Addresses (Accra: Africa Christian Press, 1985); John S. Mbiti, Bible and Theology in African Christianity (Nairobi: Oxford University Press, 1986); Kwame Bediako, Christianity in Africa: The Renewal of a Non-Western Religion (Edinburgh: Edinburgh University Press, 1996); Tite Tienou, The Theological Task of the Church in Africa (Accra: Africa Christian Press, 1996); David T. Adamo, Explorations in African Biblical Studies (Eugene: Wipf \& Stock, 2001). idem., Reading and Interpreting the Bible in Africa Indigenous Churches (Eugene: Wipf \& Stock, 2001); Victor B. Bin-Kapela, The Dialectics of Praxis and Theōria in African Philosophy: An Essay on Cultural Hermeneutics (Mankon: Langaa Research \& Pub CIG, 2011). Musa W. Dube et al., eds., Postcolonial Perspectives in African Biblical Interpretations (Atlanta: Society of Biblical Literature, 2012); Madipoane Masenya (Ngwan'a Mphahlele) and Kenneth N. Ngwa, Navigating African Biblical Hermeneutics: Trends and Themes from Our Pots and Our Calabashes (Newcastle upon Tyne: Cambridge Scholars Publishing, 2018).

9 Gerald West and Hans J.H De Wit, ed., African and European Readers of the Bible in Dialogue: In Quest of a Shared Meaning (Brill Studies of Religion in Africa 32; Leiden: Brill, 2008).

10 David T. Adamo, "What Is African Biblical Hermeneutics?" Black Theology 13/1 (2015):59-72 (62), in his quest for a distinctive African hermeneutics, critiques the European approaches. He argues that, "Eurocentric methods of interpretation are ones that include a wide variety of approaches to engaging with biblical texts. Although all these methods are honest attempts by Eurocentric scholars to understand the Bible in their Eurocentric world-view or culture, they do not adequately meet the needs of 
scholars have used among others, which is relevant to this study, is what Adamo calls using the Bible to interpret Africa which he describes as "the use of biblical texts to [engage] a particular issue in Africa or the church within a society." 11

Put differently, "after employing the historical critical method to analyse a particular biblical text the relevance of that text to Africa is illustrated,"12 implying that "African principles or methods of Biblical interpretation that can stand side by side with the Western hermeneutical mode. ${ }^{13}$ As Wuench concedes, ${ }^{14}$ "African theology always strives to be rooted in everyday life" or what Bediako referred to as "participating in." 15 This treatise is perhaps better captured by Wuench in his statement that "African theology, in contrast, gladly embraces the fact that we as human beings as well as our circumstances and cultural surroundings always were and will be part of our theology,"16 and what Snyman refers to as the ideological 'outing' of whiteness. ${ }^{17}$ In Nyiawung's thesis, such contextual issues are an obligation to exegesis today that requires "a blend between the historical data of the text, its sociological concerns and the contextual realities of the subject of exegesis." 18

\section{B ANALYSIS}

Psalm 13 commences with a sense of disequilibrium and concludes with an expression of optimism in six short verses. The subject of our investigation in this article is the seemingly quick transition from debilitating emotions to an

\footnotetext{
African people. These forms of Eurocentric hermeneutics have not addressed the abject poverty prevalent on the African continent. They have not addressed the oppression and the pain of witches and wizards, which is very real among African people. Such hermeneutics have not addressed adequately the problems of African ancestors and the question of land domination on the African continent. African culture and religion are not taken seriously in Eurocentric hermeneutics. This arises as a result of Africans having different experiences from the dominant Eurocentric world-view."

11 Adamo, "What Is African Biblical Hermeneutics?," 68.

12 Ibid., 68.

${ }^{13}$ Gold Okwuolise Anie, "Globalisation and Demythologisation in African Biblical Hermeneutics," Ogbomoso Journal of Theology 10 (2005): 68-78 (71).

14 H. Wuech, "Learning from African Theologians and Their Hermeneutics: Some Reflections from a German Evangelical Theologian," ERT 43/1 (2019): 26-39 (28).

15 Bediako, Christianity in Africa, 59.

16 Wuench, "Learning from African Theologians," 31, identifies five ways in which African Theology is different from Western theology namely: (1) the integration of real life, which leads to; (2) the integration of non-academics; (3) less strict or extreme theology; (4] the integration of the theologian personally and (5) dialogue between culture and the Bible.

17 Gerrie Snyman, “African Hermeneutics: Outing of Whiteness," Neotestamentica 42/1 (2008): 93-118.

18 Mbengu D. Nyiawung, "Contextualising Biblical Exegesis: What Is the African Biblical Hermeneutic Approach?,” HTS 69/1 (2013): 1-9 (1).
} 
indomitable disposition. How does the psalmist achieve that release of negative emotion and the embrace of the positive?

First, we need to define what an individual lament is. In general laments, either the individual or the community cries out to God, complaining about some painful situation, asking God to help and promising to offer a sacrifice to God in thanksgiving for the help received. ${ }^{19}$ Overall, this classification ranks highest compared to other categories - a fact that perhaps suggests the usefulness of the lament in addressing various conditions of human suffering. More appropriately, for our purposes, the individual laments are loaded with emotional expressions of both disillusionment and optimism. In line with our thinking, Hankle states that individual laments "address strong emotions in the form of prayer and desire for deliverance from pressing afflictions ... when working with individuals feeling stuck and trapped, these are very powerful therapeutic tools" (emphasis mine.$^{20}$

It is the emotive aspect that we are primarily concerned about as it encapsulates some of the sufferings of the present day. This concern is particularly raised by psychologists, represented here via the voice of Richardson who postulates that:

Clearly, those of us who take religious meanings and spiritual life seriously stand in need of a revised ontology of human realm and the wider world. This is especially true for those of us who are committed in our work to drawing on insights from both religion and psychology. ${ }^{21}$

Richardson proposes the need for a plausible multidisciplinary method of gaining meaning regarding human situations. In my view, this process begins an in-depth analysis of biblical material for insights into the therapeutic strategies adopted therein in dialogue with corresponding situations of human suffering.

Second, another goal of this investigation is to analyse the material in Ps 13 to reflect our serious subscription to biblical material and then to draw from our findings, principles that may be utilised in contemporary situations. In doing so, we observe that Ps 13 comprises of three stanzas, each with a designated focus. The first stanza expresses the psalmist's distress (vv. 1-3), the second petitions for deliverance (vv. 4-5), and the third expresses personal confidence in divine dealings (v. 6).

19 Robert G. Bratcher and William D. Reyburn, A Translator's Handbook on the Book of Psalms (UBSHHT; New York: United Bible Societies, 1991).

20 Dominick D. Hankle, "The Therapeutic Implications of the Imprecatory Psalms in the Christian Counselling Setting," JPsT 38/4 (2010): 275-280 (276).

21 Richardson, Frank C., "Psychology and Religion: Hermeneutic Reflections," Journal of Psychology and Theology 34/3 (2006): 232-245 (232). 


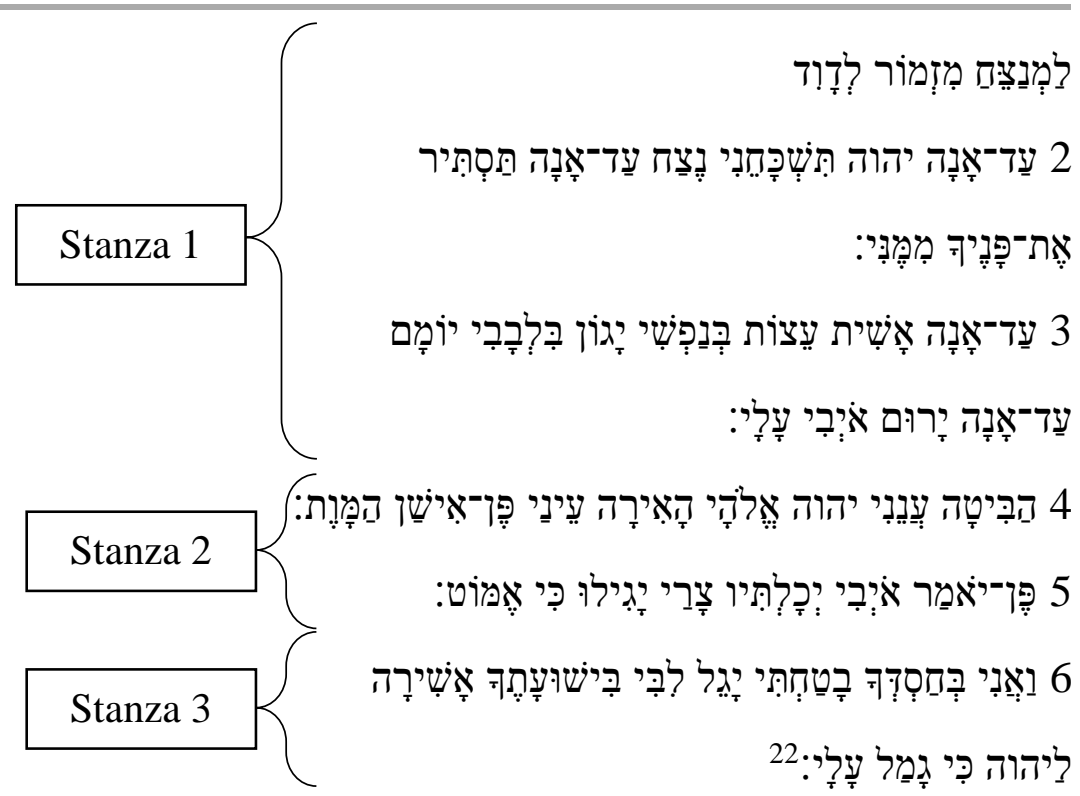

\section{$1 \quad$ The Psalmist's Distress}

The psalmist's distress, which is identified in the superscription does not spell out the mitigating historical situation. Thus, any attempt to determine the historical context may only lead to speculation. From the superscription, we also

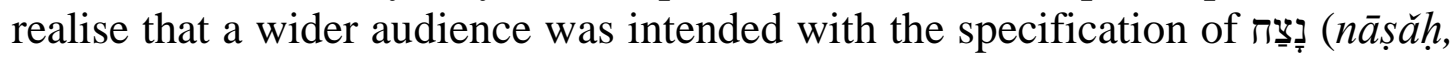
"supervisor"), understood as designating the chief musicians, because in 55 of the 65 occurrences, the noun implies acting as overseer, superintendent, director or chief. ${ }^{23}$ The chief musician would ensure the usage of the psalm in the temple and invariably by the attendees. By so doing, the psalmist's personal distress would be emblematic of that of others.

The nature of the psalmist's distress is perplexing in that it represents the effects of the experience of divine absence articulated with the interrogative עַ ( 'ăd'ān), literally, "until where," translated "how long" in the English texts. Through the repetition of the interrogative four times in the first stanza, the psalmist clearly expresses a sense of incomprehension. The adverbial "where" represents a keen awareness of the perpetual frustration emanating from the apparent divine absence. The divine absence is brought to the fore through

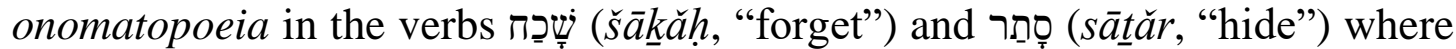
both concepts imply deliberate negligence. The former verb carries the idea of

22 The Hebrew text is from Frank I. Anderson and A. Dean Forbes, The Hebrew Bible: Andersen-Forbes Analyzed Text (Bible, OT Hebrew, Andersen-Forbes; (Ps 13:6); Logos Bible Software, 2008).

23 See H5329 in James Strong, The Exhaustive Concordance of the Bible: Showing Every Word of the Text of the Common English Version of the Canonical Books, and Every Occurrence of Each Word in Regular Order (electronic ed.; Ontario: Woodside Bible Fellowship, 1996). 
being unmindful, which is modified by the notion (nẹsăḥ, "forever") to stipulate an unlimited duration of time or of permanency. ${ }^{24}$ The latter verb which seems to imply indifference "is a figure that may not be used in some languages. In such cases, therefore, it may be necessary to switch to another figure; for example, 'turn your back to me,' 'close your eyes to me,' or 'look at me as if I were nothing." "25 Wilson asserts that the "experience of God's absence has inward emotional effects on the psalmist... inward 'wrestling' with thoughts." 26

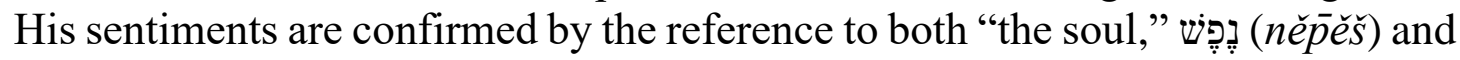

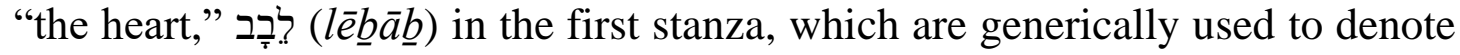
the seat of human emotion.

To underscore the poignant distress emanating from divine absence, the psalmist indicates how he resorts to self-advice as a vain attempt to deal with the daily reality of his sorrow. The ineffectuality here is derived from self-advice where the concept ('ẹșa $h$, "counsel") as the faculty of forming plans, ${ }^{27}$ more appropriately, is an allusion to the absence of the input of others. In this case, the psalmist's situation is not only exacerbated by divine absence, but equally by that of potential advisors. The outcome of the psalmist's splendid isolation elevates the feeling of perennial "sorrow," r ז anguish or grief as an emotion or attitude. ${ }^{28}$ Here we adopt Bratcher and Reyburn's recommendation that "in translation it is often necessary to distinguish between physical pain and emotional distress, distress being appropriate in this passage. Sorrow is frequently spoken of by figures of speech such as "a heavy heart" or "a spoiled heart." 29

The fourth interrogative introduces the psalmist's unnamed ('āya ăb "enemy") who is featured in the stanza that follows. The enemy is best seen in this lament as someone who expresses open hostility particularly when things go wrong for the psalmist. In this case, the enemy's sheer presence is enough to send negative emotions that deeply affect the psalmist, as we will see below.

\section{Petition for Deliverance}

The second stanza as a petition for deliverance interestingly pleads for internal resources to enable the psalmist to overcome this impasse. The request for divine

24 James A. Swanson, Dictionary of Biblical Languages with Semantic Domains: Hebrew (Old Testament) (electronic ed.; Oak Harbor: Logos Research Systems, 1997), DBLH 5905, \#2.

25 Bratcher and Reyburn, Translator's Handbook, 123.

26 Gerald H. Wilson, Psalms (vol. 1; NIVAC; Grand Rapids: Zondervan, 2002), 278.

27 Wilhelm Gesenius and Samuel P. Tregelles, Gesenius' Hebrew and Chaldee Lexicon to the Old Testament Scriptures (trans. of Lexicon manuale Hebraicum et Chaldaicum in Veteris Testamenti Libros, a Latin version of the work first published in 1810-1812 under the title, Hebräisch-deutsches Handwörterbuch des Alten Testaments; Bellingham: Logos Research Systems, 2003), 647.

28 See H3015 in Strong, Exhaustive Concordance, 1507.

29 Bratcher and Reyburn, Translator's Handbook, 124. 
audience expressed through the verbs נָָבֵט (nābăt,, "look at"), a reversal of the hiding of one's face; and ('ānāh, "answer"), to "respond to a question, or circumstance with a verbal reply or even occasionally an action." ${ }^{30}$ The actualisation of the divine presence that is implied here refers specifically to the enlightening of the psalmist's eyes. The phrase הָאִירָה עִינוּנ ought to be regarded as a perspectival request towards personal rejuvenation. Keil and Delitsch affirm that to "lighten the eyes that are dimmed with sorrow and ready to break, is equivalent to imparting new life (Ezra 9:8), which is reflected in the fresh clear brightness of the eye (1 Sam. 14:27, 29)." ${ }^{31}$ Bratcher and Reyburn comment that:

The phrase lighten my eyes (literally "give light to my eyes") means to restore one's strength, health, vigor (see Ps 38.10; 1 Sam 14.27, 29; Ezra 9.8 ), since bright eyes were considered the sign of good health. NJV has "Restore the luster to my eyes." In many languages it is possible to use a different figure to express lighten my eyes, with the sense of giving strength to someone; for example, "make me strong like a young man," "give me fresh breath," or "make my hands strong. ${ }^{32}$

In my view, this process envisages divine presence, since God is the

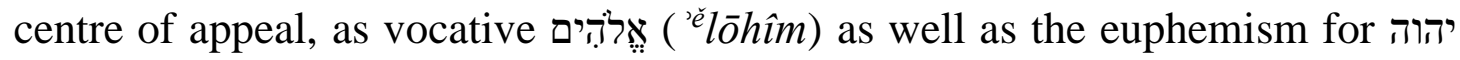
$(y h w h)$, that is, Adonai is employed in this stanza. It is his presence that invokes the restoration of the much-depleted internal resources necessary to reverse the psalmist's despondency. The petition here also particularises two phobias that the psalmist would not want his situation to deteriorate into-both horrors are introduced by the consequential conjunction of a negative purpose, implying some apprehension or worry of a possible future event. ${ }^{33}$ The first disturbing aspect that the psalmist deplores is what he calls the

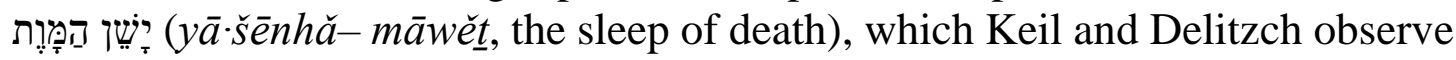
as "the accusative of effect or sequence: to sleep so that the sleep becomes

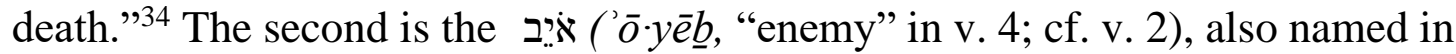
the plural construct צֵ (șarr) in the parallel line that ensues to describe the psalmist's awareness of succumbing to his demise as psychological victory for his foes. In fact, the verb מוט (môt) - "totter" according to one lexical entry means "to slip, totter, stagger, quake, shake, i.e., make random motions which may result in an object falling, implying lack of motor control due to weakness

30 Swanson, Dictionary, DBLH 6699, \#1.

31 Carl F. Keil and Franz Delitzsch, Psalms (vol. 5 of Commentary on the Old Testament; Peabody: Hendrickson, 2002), 124.

32 Bratcher and Reyburn, Translator's Handbook, 124.

33 Swanson, Dictionary, DBLH 7153, \#1.

34 Keil and Delitzsch, Psalms, 124. 
or other factors." ${ }^{35}$ It describes the incapacitation that the psalmist may suffer if divine aid is not rendered.

\section{$3 \quad$ Personal confidence in divine dealings}

The third stanza, which expresses confidence in divine dealings, is wholly positive. It is quite a dramatic shift from the sentiments in the first two stanzas. To begin, the stanza opens with the contrastive conjunction - ? $(w-)$ "but,"

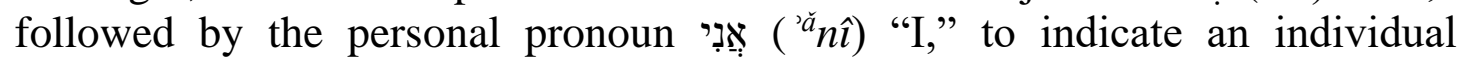
conviction not affected by what precedes it. He declares his דִִ̣ (bātăh, "trust"), which is a total reliance on divine חִ (hěsěd, "loyalty"), better described as love or affection that is steadfast based on a prior relationship. ${ }^{36}$ Commonly translated steadfast love or unfailing love, (hěséd ), according to Bratcher and Reyburn, translates a complex set of relations and emotions to render the idea of "I will place my heart upon you because you love me faithfully" or "because you love me all the time." ${ }^{37}$ The sense of emotion here is further transposed into a song when the psalmist proclaims (gîl, "rejoice"), which means to be glad and joyful, that is, to be in a state or attitude of favourable circumstance. ${ }^{38}$ Once again, the (le $\underline{\text { b }}$, "heart"; cf. v. 2), as the seat of emotions, is identified as the

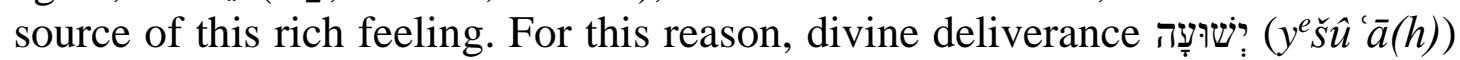
is not questionable but a sure reality. Having said that, the psalmist can understandably close with the expressed desire to sing to Yahweh because of

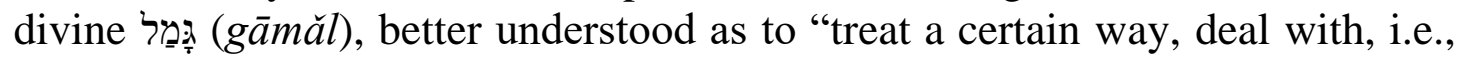
commit energy and motion to any kind of action or recompense, deal in repayment." ${ }^{39}$ In this case, it means to deal favourably, which seems antithetical to the sentiments the psalmist commenced with. How does he achieve that transition? Let us turn our attention to that at this point.

\section{REFLECTION ON ADOPTED THERAPEUTIC STRATEGIES}

Psalm 13, as an individual lament attributed to David, provides, in Harrington's words, a "healthy vehicle for the expression of pain and the pursuit of dialogue with God in difficult times." ${ }^{40}$ One may surmise a few such strategies from a close analysis of the text.

First, the psalmist vocalises his frustration. Notice the frequency of the personal pronoun (ִּנִ ( $\left.{ }^{\prime a} n \hat{\imath}\right)$ or the first person singular verbs throughout the psalm. At the same time, the speaker raises important questions that seek real

35 Ibid. 4572, \#1.

36 Ibid., 2876, \#1.

37 Bratcher and Reyburn, Translator's Handbook, 125.

38 Ibid., 1635.

39 Ibid., 1694, \#2.

40 Hannah K. Harrington, "Lament or Complaint? A Response to Scott Ellington, Risking Truth: Reshaping the Word through Prayer of Lament," JPT 18/2 (2009): 177-181 (181). 
resolution. The interrogatives, which have the effect of heightening or intensifying the theme of supplication ${ }^{41}$ as well as the inward turmoil in the absence of divine intervention, leading to an anticipation of rapid decline, or as Wilson calls it, of depression, defeat and death, ${ }^{42}$ all raise imperative questions:

The questions at issue here are not simple requests for knowledge but express deep human misgivings about the character and activity of God and their effect on human life... Such questions reveal a faith seeking to understand in the midst of painful experiences that shake the very foundation of believing. ${ }^{43}$

It is in raising and wrestling with these questions that one works his or her way towards a resolution. Failure to raise and to wrestle with these critical issues can often result in self-condemnation.

Second, the free expression of emotions offers release. Psalm 13 is highly emotive, with the sense of abandonment that the psalmist experiences lending itself to self-determination. "If God is out of the picture, then humans are left entirely to their own devices. The only avenue available is to rely on self-power and self-control." 44 As stated above, we recall Hanke's observation that "because the psalms lend themselves nicely to emotional expression, they are an excellent vehicle for resolving emotional stress leading to psychological and spiritual benefits." He adds that, "negative emotions can play a part in healing from past trauma when properly experienced." 45 There is widespread agreement among psychologists that the expression of emotions has important effects in resolving emotional difficulties. Holding back is therefore counterproductive.

Third, the psalmist maintains a divine orientation. In each stanza, he explicitly mentions God by name (yhwh in vv. 2, 4 and 6; and 'ělohîm in v. 4) and implicitly via the personal pronouns at least nine times. Even though the psalmist commences with sentiments that at best can be described as anti-God, what we discover is that his fixation on Yahweh does not waver. By employing the covenantal vocative here, he effectively questions why a God known to be loyal allows prolonged suffering. We should note that the questions are directed at Yahweh and no other. Wilson comments thus:

The lament psalms direct their appeal to God himself, seeking deliverance from trouble and distress. The world of the lamenting psalmist is fully aware of the possibilities and realities of suffering, disorder, sin, and oppression that are a part of the living in the world... Experience of pain often drives the psalmist to question the sure foundation represented by God's creative power and sustaining

41 Bratcher and Reyburn, Translator's Handbook, 122.

42 Wilson, Psalms, 278.

43 Ibid., 278.

44 Ibid., 283.

45 Hankle, "Therapeutic Implications," 275-280. 
authority. They experience God as distant (even hostile, as in Psa. 88), and like Job muster arguments to motivate him to act in their behalf. ${ }^{46}$

It is therefore conceivable that the psalmist assumes a living relationship with God as something not to be taken for granted. It is this very relationship carved out in covenantal jargon that he presumes in this situation. Craigie maintains that "as a member of the covenant people, his expectation was to be remembered by God and to see that light of his countenance (Num 6:25-26), but the long absence of such privileges evoked the anguish cry of lament." ${ }^{\prime 7}$ It is this relationship that cannot be shaken if one is to survive painful experiences. Harrington concludes that "lament is a healthy way to deal with grief because it fosters relationship with God and seeks dialogue with him." ${ }^{48}$ For Ellington,

Lament is neither a cry of pain nor is it simply a complaint, though both may be contained in the lament prayer. Lament is prayer offered in the context of relationship... If pain and protest alone are not sufficient to constitute biblical lament, what is its basis? Biblical lament, while it does include tears, pleas, complaints and protests is something more. It is the experience of less suffered within the context of relatedness. A relationship of trust, intimacy and love is necessary for genuine lament. ${ }^{49}$

For this reason, the psalmist thus recalls divine credentials to remind himself of the unchanging nature of God despite his negative personal circumstances. It is in recalling divine loyalty, deliverance and recompense (v. 6) that the psalmist is able to end with positive emotions through rejoicing and breaking out in song. Thus, though the psalmist is blatantly self-focused, he paradoxically looks beyond self for a solution. Invariably, he enables us to understand that by definition a lament is not merely an unhealthy complaint but a well-considered prayer. Ellington comprehensively describes lament as follows:

Lament, then, is a prayer addressed to God that moves beyond expression of pain and complaint. It petitions God on the basis of a relationship that is potentially imperilled by experiences of God's silence, hiddenness. ${ }^{50}$

As such, a lament demands that we carefully consider as much as the composer did that it is self-expression in difficult times. Harrington correctly surmises that "lament in a time of suffering is not the difficult activity, but rather

\footnotetext{
46 Wilson, Psalms, 65.

47 Peter C. Craigie, Psalm 1-50 (WBC; Waco: Word Press, 1983), 142.

48 Harrington, "Lament or Complaint?," 177.

49 Scott A. Ellington, "So Much Still to Do: A Response to Mare, Hannah Harrington and Blaine Charrette," JPT 18/2 (2009): 186-193 (188).

50 Ellington, "So Much Still to Do," 188.
} 
continued praise to God that He is good despite the suffering." ${ }^{51}$ He submits, and we concur, that we need "to face the problem of suffering within the context of the believing community and to recognize lament as a healthy vehicle for the expression of pain and the pursuit of dialogue with God in difficult times." 52 In the end, this article affirms that a lament reveals a correlation between healthy religious beliefs and practices and emotional wellbeing.

\section{BIBLIOGRAPHY}

Adamo, D. Tuesday. Explorations in African Biblical Studies. Eugene: Wipf \& Stock, 2001.

. Reading and Interpreting the Bible in African Indigenous Churches. Eugene: Wipf \& Stock, 2001.

. "What Is African Biblical Hermeneutics?" Black Theology 13/1 (2015): 5972.

Anderson, Frank I. and A. Dean Forbes. The Hebrew Bible: Andersen-Forbes Analyzed Text. Bible, OT Hebrew, Andersen-Forbes (Ps 13:6). Logos Bible Software: Lexham Press, 2008.

Anie, Gold Okwuolise. "Globalization and Demythologization in African Biblical Hermeneutics." Ogbomoso Journal of Theology (2005): 68-78.

Anon. Nobel Peace Prize Winner: Denis Mukwege from DR Congo. Cited 10 August 2020. Online: https://www.bbc.com/news/world-africa-45759304. BBC, 5 October 2018.

Bediako, Kwame. Christianity in Africa: The Renewal of a Non-Western Religion. Edinburgh: Edinburgh University Press, 1996.

Bin-Kapela, Victor B. The Dialectics of Praxis and Theōria in African Philosophy: An Essay on Cultural Hermeneutics. Mankon, Bamenda: Langaa Research \& Pub. CIG, 2011.

Boyer, T. "Psalms of Lament: Songs of a Fading Shadow." Pastoral Music 37/4 (2013): $22-24$.

Bratcher, Robert G. and William D. Reyburn. A Translator's Handbook on the Book of Psalms. Helps for Translators 2. New York: United Bible Societies, 1991.

Craigie, P.C. Psalm 1-50. Word Biblical Commentary. Waco: Word Press, 1983.

De Wit, H. and Gerald O. West. African and European Readers of the Bible in Dialogue: In Quest of a Shared Meaning. Studies of Religion in Africa 32. Leiden: Brill, 2008.

Dube, Shomanah MusaW. et al, eds. Postcolonial Perspectives in African Biblical Interpretations. Atlanta: Society of Biblical Literature, 2012.

Ellington, Scott A. "So Much Still to Do: A Response to Leornard Mare, Hannah Harrington and Blaine Charrette." Journal of Pentecostal Theology 18 (2009): 186-193.

Gerhardt, Elizabeth. The Cross and Gendercide: A Theological Response to Global Violence against Women and Girls. Downers Grove: InterVarsity Press, 2014.

Gesenius, Wilhelm and Samuel P. Tregelles. Gesenius' Hebrew and Chaldee Lexicon to the Old Testament Scriptures. Translation of the Author's Lexicon Manuale

51 Harrington, “Lament or Complaint?” 180.

52 Ibid., 181. 
Hebraicum et Chaldaicum in Veteris Testamenti Libros, A Latin Version of the Work First Published in 1810-1812 under Title: Hebräisch-Deutsches Handwörterbuch des Alten Testaments. Bellingham: Logos Research Systems, 2003.

Girard, M. "The Psalms of Lament." The Bible Today 48/3 (2010): 135-141.

Hankle, Dominick D. "The Therapeutic Implications of the Imprecatory Psalms in the Christian Counselling Setting." Journal of Psychology and Theology 38/4 (2010): 275-280.

Harrington, Hannah K. "Lament or Complaint? A Response to Scott Ellington, Risking Truth: Reshaping the Word through Prayer of Lament." Journal of Pentecostal Theology 18 (2009): 177-181.

Honeycutt, James M. et al. "Individual Differences in Catharsis, Emotional Valence, Trauma Anxiety, and Social Networks among Hurricane Katrina and Rita Victims." Southern Communication Journal 73/3 (2008): 229-242.

Jones, L.C. "The Psalms of Lament and the Transformation of Sorrow." The Journal of Pastoral Care and Counselling 61/1-2 (2007): 47-58.

Joo, Jonghun. 2017. "The Psalms of Lament: Prospects for Renewing Kenyan Evangelical Worship." Worship 91 (2017): 351-367.

Kato, Byang H. Biblical Christianity in Africa: A Collection of Papers and Addresses. Theological Perspectives in Africa 2. Achimota: Africa Christian Press, 1985.

Keil, Carl F. and Frank Delitzsch. Commentary on the Old Testament. Vol 5. Peabody: Hendrickson, 2002.

Masenya, Madipoane J. (Ngwan'a Mphahlele) and Kenneth N. Ngwa, eds. Navigating African Biblical Hermeneutics: Trends and Themes from Our Pots and Our Calabashes. Newcastle upon Tyne: Cambridge Scholars Publishing, 2018.

Mbiti, John S. Bible and Theology in African Christianity. Nairobi: Oxford University Press, 1986.

Mendy, Gabriel. "The Theological Significance of the Psalm of Lament." American Theological Inquiry 8/1 (2015): 61-71.

Nyiawung, Mbengu David. "Contextualising Biblical Exegesis: What Is the African Biblical Hermeneutic Approach?” Hervormde Teologiese Studies 69/1 (2013): 1-9.

Peres, Andréa Carolina Schvartz. "Campos de Estupro: As Mulheres e a Guerra na Bósnia. Rape Camps: Women and War in Bosnia 37/37 (2011): 117-162.

Richardson, Frank C. "Psychology and Religion: Hermeneutic Reflections." Journal of Psychology and Theology 34/3 (2006): 232-245.

Ross, C. “The Longest War": Gendercide.” Baptistic Theologies 9/1 (2017): 49-65.

Scheff, Thomas. "Catharsis and Other Heresies: A Theory of Emotion." Journal of Social, Evolutionary and Cultural Psychology 1/3 (2007): 98-113.

Snyman, Gerrie. "African Hermeneutics: Outing of Whiteness." Neotestamentica 42/1 (2008): 93-118.

Strong, James. The Exhaustive Concordance of the Bible: Showing Every Word of the Text of the Common English Version of the Canonical Books, and Every Occurrence of Each Word in Regular Order. Electronic Edition. Ontario: Woodside Bible Fellowship, 1996.

Swanson, J. Dictionary of Biblical Languages with Semantic Domains: Hebrew (Old Testament). Electronic Edition. Oak Harbor: Logos Research Systems, 1997. 
Tienou, T. The Theological Task of the Church in Africa. Accra: Africa Christian Press, 1996.

Waltman, J. C. "Psalms of Lament and God's Silence: Features of Petition not Yet Answered." The Evangelical Quarterly 89/3 (2018): 209-221.

Wilson, G.H. Psalms V1. The NIV Application Commentary. Grand Rapids: Zondervan, 2002.

Wuench, Hans-Georg. "Learning from African Theologians and Their Hermeneutics: Some Reflections from a German Evangelical Theologian." Evangelical Review of Theology 43/1 (2019): 26-39.

Sampson S. Ndoga is Extraordinary Lecturer in the Department of Old Testament and Hebrew Scriptures, Faculty of Theology and Religion, University of Pretoria._Email address: samndoga@gmail.com. ORCID: https://orcid.org/0000-0001-7448-3437 